\title{
WEWNĘTRZNA RACJONALNOŚĆ NAUK HISTORYCZNYCH
}

\section{ABSTRACT}

\section{THE INTERNAL RATIONALITY OF HISTORY}

This article is an attempt to show a possible way to find out, what kind of rationality characterizes history. It bases on philosophical assumption that idea of rationality is always directly connected with idea of truth. This connection was presented in the article as an argument for treating the notion of historical truth as the right basis for analyze rationality of history. In light of modern theory of history, historical truth can be see from angle of the notion of truth proposed by Hilary Putnam and Willard Van Orman Quine. It means that it can be understand as the internal truth: truth dependent on its context. In accordance with main assumption, this fact allows history to try to think about its own rationality in similar way: to define it as internal (contextual) rationality, which accurately mirrors the individual character of historical cognition. The article points out theoretical problems potentially connected with above conception of rationality. Question, whether history has ability to analyze the rationality by its own instruments, was underlined as one of the most important.

\section{KEYWORDS:}


Pytanie o racjonalność nauk historycznych: pytanie o to, jak ową racjonalność rozumieć i co na płaszczyźnie badań oraz wiedzy historycznej może ją wyznaczać, jest pytaniem o konotacjach ewidentnie filozoficznych. Jest to, można by rzec, filozoficzne pytanie historii, na co wskazuje nie tylko silne zakorzenienie tematu rozumu i rozumności w filozofii, ale także jego wysoce teoretyczny (metodologiczno-epistemologiczny) charakter. Historia, pytając o swą racjonalność, porusza problem odnoszący się do jej własnej „rzeczywistości teoretycznej” - obszaru, który w ślad za Louisem Althusserem pojmować możemy jako tożsamy z tym, co filozoficzne. Pytanie o racjonalność nauk historycznych wydaje się być tej natury, że aby móc próbować na nie odpowiedzieć, należy brać pod uwagę zarówno specyficzne aspekty nauki o dziejach, jak i wyniki badań filozoficznych w zakresie refleksji nad szeroko pojętą sferą ratio.

W świetle tych ostatnich, sposób rozumienia racjonalności na gruncie różnych dyscyplin naukowych, w tym również na gruncie nauk historycznych, wydaje się w istotnej mierze zależeć od pozycji, jaką zajmują w nich wartości poznawcze. Za kluczowo ważną w tym kontekście uznać należy pozycję wartości prawdy, która szczególnie z perspektywy tradycyjnej filozofii poznania pozostaje z racjonalnością w najściślejszym związku. Jak zauważa Władysław Stróżewski, tradycyjny racjonalizm wskazuje na ów związek w sposób szczególnie wyraźny. W świetle ustaleń Stróżewskiego,

„prawda $[\ldots]$ jest ostatecznym usprawiedliwieniem racjonalizmu $[\ldots]$. Żaden autentyczny racjonalizm nie rezygnuje z bycia prawdziwym. Prawdziwość jest ostateczną racją racjonalizmu. Jeśli na miejsce prawdy jako najwyższej wartości i ostatecznego celu postawione jest coś innego, możemy być pewni, że nie mamy do czynienia z czystym racjonalizmem. [... ] Ani poznanie dla poznania, ani myślenie dla myślenia, lecz poznanie dla prawdy i myślenie w celu jej osiągnięcia są autentycznymi wyznacznikami tego kierunku”'.

Tradycyjny racjonalizm, wiążąc z sobą ściśle prawdę i racjonalność, daje nam pośrednio do zrozumienia, że znając obowiązującą w danej nauce wykładnię pojęcia „prawdy” - znając akceptowany w niej status i znaczenie tej kategorii - możemy powiedzieć coś na temat uznawanego przez tę naukę pojęcia „racjonalności”. Skoro granicą naszej kultury, jak twierdzi Leszek Kołakowski, jest przekonanie, że bycie rozumnym oznacza nieodzownie wolę poznawania prawdy ${ }^{2}$, to mamy podstawę, by sądzić, iż stosunek określonej dziedziny do racjonalności jej samej będzie zawsze

\footnotetext{
W. Stróżewski, Racjonalizm i metaracjonalizm, [w: Istnienie i sens, Kraków 2005, s. 448-449.

L. Kołakowski, Jestże dla prawdy przyszłość jaka?, [w: ] Czy Pan Bóg jest szczęśliwy i inne pytania, Kraków
} 2009, s. 286-287. 
w pewien sposób analogiczny do stanowiska, jakie dziedzina ta zajmuje w kwestii prawdziwości swych poznań.

Koncepcje prawdy i racjonalności, skorelowane w obrębie klasycznych filozofii racjonalistycznych, współokreślają stanowisko znane jako realizm metafizyczny. Zgodnie z tym stanowiskiem, by przywołać tu ujęcie Hilarego Putnama, „[... ] można myśleć i mówić o rzeczach takich, jakimi one są, niezależnie od samego umysłu, a czynić tak można dzięki relacji »korespondencji «, która zachodzi między terminami naszego języka a pewnego rodzaju niezależnymi od umysłu jestestwami”’ . Omawiana doktryna, przyjmując tak zwaną „korespondencyjną” koncepcję prawdy (prawdy jako zgodności rzeczy i intelektu lub odwrotnie), zakładała, że rozum co do swych zasad i praw jest izomorficzny względem rzeczywistości i jako taki zdolny do jej adekwatnego odwzorowywania w poznaniu. Rozumiejąc prawdę „korespondencyjnie” - jako przyporządkowanie czy też przyrównanie intelektu do rzeczy, rzeczy do intelektu lub wzajemnie obu elementów do siebie - filozofia ta przypisywała rozumowi funkcję władzy realizującej poznanie obiektywne: poznanie ujmujące prawdziwie obiektywnie istniejącą, niezależną rzeczywistość ${ }^{4}$.

Nasuwa się pytanie, w jakiej mierze współczesny stan wiedzy teorio-historycznej uzasadnia przypisywanie naukom historycznym racjonalności skorelowanej z „korespondencyjną" koncepcją prawdy? W jakiej mierze obowiązujące lub postulowane współcześnie pojęcie prawdy historycznej pozwala zakładać, że racjonalność naukowej historiografii, to obiektywnie usankcjonowana dyspozycja do adekwatnego poznawania dziejów? Czy sposób, w jaki teoria historii rozumie obecnie prawdę poznania historycznego, uprawomocnia stosowanie do nauki o historii tradycyjnego, filozoficznego pojęcia racjonalności, czy może skłania raczej do poszukiwania innego ratio: swoistej racjonalności tego, co historyczne?

Nie ulega wątpliwości, że we współczesnej teorii historii daje o sobie znać dystans wobec prawdy pojętej jako adaequatio rei et intellectus. Dla wielu współczesnych teoretyków historii charakteryzowanie wiedzy historycznej za pomocą narzędzi „korespondencyjnej" teorii prawdy nie znajduje uzasadnienia. Za symptomatyczne dla tego punktu widzenia uznać można poglądy prezentowane przez Wojciecha Wrzoska, Ewę Domańską i Jerzego Topolskiego. Obecnie, jak twierdzi Wojciech Wrzosek, obowiązywanie określonej wizji świata historycznego nie zależy od tego, czy jest ona bądź nie jest prawdziwa w tradycyjnym sensie, ale od tego, czy wyartykułowano ją przy pomocy metafor historiograficznych trafiających do zbiorowej wrażliwości ludzi

H. Putnam, Dlaczego świat nie jest wyrobem gotowym, [w: ] Wiele twarzy realizmu i inne eseje, Warszawa 1998, s. 225.

4 W. Stróżewski, Racjonalizm i..., [w: ] Istnienie i..., s. 449-450. 
danego $\mathrm{czasu}^{5}$. Rozważając otwarcie się w teorii historii na kategorie filozofii życia oraz późniejszy lingwistyczny zwrot w historiografii lat osiemdziesiątych ubiegłego wieku, Ewa Domańska pokazuje, że obiektywna prawda o przeszłości nie jest już i nie musi być wyłącznym celem uprawiania badań historycznych - że wobec jej braku historia nie traci wcale swej racji bytu. Dzieje się tak, ponieważ wkroczenie kategorii „życia” do historii przenosi uwagę historyków z płaszczyzny tego, co historycznie obiektywne, na poziom subiektywnego przeżywania dziejów przez człowieka: stawia przed nimi zadania o wymiarze nie tyle poznawczym, co egzystencjalnym - na przykład moralnym. Dzieje się tak, ponieważ zwrot lingwistyczny zaciera granicę pomiędzy historiografią a literaturą (faktem historycznym a fikcją literacką) i powoduje, że dostępne badaczom źródła historyczne (nawet te poddane krytyce) nie mogą przestać być językowymi konstrukcjami: interpretacjami, których nieuchronny subiektywizm odbiera im status podstawy obiektywnego poznania przeszłości ${ }^{6}$.

Jerzy Topolski, broniąc tezy o niemożliwości utrzymania w naukach historycznych klasycznego pojęcia prawdy ${ }^{7}$, podnosi, podobnie jak Ewa Domańska, kwestię skutków zwrotu językowego i kryzysu tak zwanej zwierciadlanej koncepcji języka, zgodnie z którą język oraz to, o czym w języku jest mowa, łączy naturalny związek. W ocenie Topolskiego, zakwestionowanie neutralności języka względem procesów poznawczych i uznanie wpływu tego, co językowe, na kształt ludzkiej wiedzy wyklucza, iżby klasyczne rozumienie prawdy można było zachować choćby w odniesieniu do jednostkowych zdań empirycznych historii, jakie znamy z kronikarskich zapisów - zdań stwierdzających, iż wtedy i tam wydarzyło się to lub tamto. Wykazanie, że zdania typu: „w roku 1789 zburzono Bastylię” adekwatnie „korespondują” z obiektywnym stanem rzeczy z przeszłości, jest - z teoriopoznawczego punktu widzenia - wysoce problematyczne. Nie sposób w celu przeprowadzenia badań prawdziwościowych wypreparować owych zdań ze złożonej struktury narracyjnej całości, nie odbierając im przy tym ich znaczenia, które mają one dzięki wielorakim powiązaniom z innymi zdaniami (także ogólnymi) tylko w ramach narracji. Nie sposób też zdań tych odizolować od kontekstu retoryczno-perswazyjnego całości narracyjnej, który to kontekst, służąc prezentacji przekonań historyka nie podlega tradycyjnej kwalifikacji prawdziwościowej. Narra-

5 W. Wrzosek, Metafory historiograficzne w pogoni za utuda prawdy, [w:] red. E. Domańska, J. Topolski, W. Wrzosek, Między modernizmem a postmodernizmem. Historiografia wobec zmian w filozofii historii. Poznań 1994, s. $14-15$.

E. Domańska, Filozoficzne rozdroża historii, [w: ] red. E. Domańska, J. Topolski, W. Wrzosek, Między modernizmem a postmodernizmem..., s. 19-30.

J. Topolski, Problemy prawdy historycznej, [w:] red. E. Domańska, J. Topolski, W. Wrzosek, Między modernizmem a postmodernizmem..., s. 34 . 
cyjne zintegrowanie jednostkowych stwierdzeń historycznych z owym kontekstem stawia je w tym samym położeniu - poza zasięgiem klasycznego kryterium prawdy ${ }^{8}$.

Obecność wyżej przytoczonych poglądów we współczesnej teorii historii prowadzi do zwątpienia w „korespondencyjny”, obiektywny sens prawdy historycznej, nie usuwając jednak jej samej (kategorii prawdy w ogóle) z nauk historycznych ${ }^{9}$. W tej kwestii, na co zwraca uwagę Krzysztof Zamorski, ustalenia teorii historii odbiegają wyraźnie od tego, co sugerować wydaje się dominująca praktyka naukowa. Postmodernistyczna krytyka obiektywizmu nauk historycznych, choć traktowana bywa jako zapowiedź pojawienia się zupełnie nowego rodzaju historiografii, nie wytworzyła dotąd właściwego sobie dojrzałego paradygmatu, co tłumaczyć może, dlaczego historiograficzna praxis nie opiera się na niej w wymiarze powszechnym ${ }^{10}$. Faktem jest, że pozostaje ona blisko dwóch w pełni rozwiniętych paradygmatów naukowej historii: klasycznego historyzmu i modernistycznego paradygmatu historii jako nauki społecznej. Elementem ich obu jest wiara w obiektywne poznanie przeszłości i pozytywną rolę władz rozumu w tym procesie ${ }^{11}$. Wpływ tym podobnych założeń na świadomość zawodową historyków oraz ich codzienną praktykę badawczą jest wyraźny; historycy, podejmując badanie wybranego obszaru dziejów (czy to pod kątem faktów indywidualnych, czy to całościowych zjawisk i procesów), suponują, iż sposób, w jaki reflektują oni dany fragment przeszłości, podlega obiektywizacji, to znaczy spełnia wymóg stałej kontroli przez doświadczenie: czyni zadość przekonaniu, jakoby narracja o dziejach dawała się uzgodnić z samymi dziejami za pośrednictwem źródeł i zastanej wiedzy historycznej ${ }^{12}$.

Założenie o możliwości dokonywania tak rozumianej obiektywizacji refleksji historycznej wpisuje tę refleksję w przestrzeń oddziaływania kategorii prawdy. Owa obiektywizacja, jak twierdzi Krzysztof Zamorski, jest tu „[...] praktycznym wyrazem ludzkiej woli zbliżania się do prawdy”|3. Istnienie takiej woli potwierdzają także auto-

8 J. Topolski, Problemy prawdy..., [w:] red. E. Domańska, J. Topolski, W. Wrzosek, Między modernizmem a postmodernizmem..., s. 35-38.

9 Analizując sytuację kryzysu idei prawdy w naukach społecznych i humanistyce, Felipe Fernandez-Armesto podkreśla, że dla historii stan ten jest szczególnie trudny do zaakceptowania z uwagi na wciąż odczuwalne oddziaływanie idei Leopolda Rankego: przede wszystkim idei obiektywnie prawdziwego oglądu przeszłości. Aprobując choćby po części zasadę poznania historycznego oczyszczonego z wszelkiej subiektywności, wszelkiego wartościowania czy moralizatorstwa, historyk - także ten współczesny - przywiązany jest do koncepcji prawdy obiektywnej bardziej aniżeli przedstawiciele innych nauk. Fernandez-Armesto uważa na tej podstawie, że historia bez kategorii prawdy i obiektywności jest trudna do uzasadnienia. Historycy, jak twierdzi, potrzebują ich, by uprawomocnić podejmowane przez siebie badania. F. Fernandez-Armesto, Historia prawdy, Poznań 1999, s. 207-208.

10 K. Zamorski, Dziwna rzeczywistość: wprowadzenie do ontologii historii, Kraków 2008, s. 136.

11 Tamże, s. 197.

12 Tamże, s. $138-141$.

13 Tamże, s. 138. 
rzy przywołani wcześniej jako krytycy historycznych zastosowań klasycznej definicji prawdy. Jerzy Topolski dostrzega, że praca historyków - mimo teoretycznych zastrzeżeń - ukierunkowana jest na prawdę i z moralnych względów wartościuje ten fakt pozytywnie $^{14}$. Ewa Domańska stwierdza jednoznacznie: „[... ] ani narratywistyczna filozofia historii, ani żaden »nowoczesny« historyk nie negują istnienia rzeczywistości prawdy jako takiej”'15.

Przywołane wyżej poglądy wskazują, jak można by sądzić, na pewne teoretyczno-praktyczne pęknięcie we współczesnym myśleniu o prawdzie historycznej. Sytuacja wydaje się wymagać podejścia, które zachowując krytyczny dystans względem naiwnego realizmu, respektowałoby umocowaną w praktyce historii orientację na to, co prawdziwe. Dążenie do prawdy historycznej przy jednoczesnym odrzuceniu jej „korespondencyjnej” wykładni wskazuje, że w naukach historycznych istnieje obecnie zapotrzebowanie na inną niż klasyczna ideę prawdziwości. Można zgodzić się z Jerzym Topolskim, że koncepcja prawdy historycznej odpowiadająca współczesnym oczekiwaniom powinna wziąć pod uwagę między innymi teorie prawdy Hilarego Putnama i Willarda V. Ormana Quine’a. Sposób, w jaki obaj wspomniani filozofowie podchodzą do problemu prawdy, wpisuje się w punkt widzenia pragmatyzmu, co w tym miejscu oznacza przede wszystkim tyle, iż użycie predykatu „prawdziwy” w odniesieniu do zdań o przeszłości ma wyłącznie charakter wewnętrzny: jest ograniczone do określonego kontekstu i nie wymaga ustaleń co do zgodności owych zdań z zewnętrzną wobec historyka rzeczywistością dziejów ${ }^{16}$.

W ujęciu Quine'a, prawda zyskuje wymiar wewnętrzny, będąc w znacznym stopniu rezultatem immanentnych procesów nauki: procesów niezdeterminowanych bezwzględnie danymi doświadczenia, a przede wszystkim uwarunkowanych pragmatycznie - mających na celu zachowanie równowagi nauki jako całości ${ }^{17}$. Rozluźniając

14 J. Topolski, Problemy prawdy..., [w:] red. E. Domańska, J. Topolski, W. Wrzosek, Między modernizmem a postmodernizmem..., s. 34 .

15 E. Domańska, Filozoficzne rozdroża..., [w:] red. E. Domańska, J. Topolski, W. Wrzosek, Między modernizmem a postmodernizmem..., s. 23.

16 J. Topolski, Problemy prawdy..., [w: ] red. E. Domańska, J. Topolski, W. Wrzosek, Między modernizmem a postmodernizmem..., s. 33-35.

17 W. V. O. Quine, Dwa dogmaty empiryzmu, [w: ] Z punktu widzenia logiki. Eseje logiczno-filozoficzne, Warszawa 1969, s. 64-70. Jak pisze Quine, nauka „[... ] podobna jest do pola siły, którego warunkami brzegowymi jest doświadczenie. Konflikt z doświadczeniem na brzegach pola powoduje odpowiednie przystosowania w jego wnętrzu. Niektórym ze zdań zostaje przypisana inna wartość logiczna. Zmiana oceny jednych zdań pociąga zmianę oceny innych za sprawą ich logicznych związków, przy czym prawa logiki są po prostu dalszymi twierdzeniami systemu, pewnymi innymi elementami pola [...]. Pole jako całość jest jednak na tyle niezdeterminowane przez swe warunki brzegowe, tj. przez doświadczenie, że istnieje znaczna swoboda wyboru zdań, które wobec danego konfliktu $\mathrm{z}$ doświadczeniem mają być >> przecenione<<. Żadne poszczególne świadectwo doświadczenia nie jest związane z jakimś określonym zdaniem z wnętrza pola; związek ten ma co najwyżej charakter pośredni, za sprawą równowagi pola jako całości”. W. V. O. Quine, Dwa dogmaty..., [w: ] Z punktu widzenia..., s. 65. 
związki „korespondencji” pomiędzy twierdzeniami uznawanymi za prawdziwe a zewnętrznymi stanami rzeczy, które mają im odpowiadać, Quine dostrzega, jak dalece konstatowanie prawdy bądź jej kwestionowanie w nauce oparte jest na wewnętrznych mechanizmach samej nauki. Według Quine’a, „każde zdanie może obowiązywać niezależnie od doświadczenia, o ile dokonamy dostatecznie daleko idącego przystosowania reszty systemu"18.

Hilary Putnam, wychodząc od pragmatystycznie zinterpretowanej przez siebie filozofii Kanta, zakłada, że przedmioty doświadczenia zależą od naszych teoretycznych konstrukcji - że nie są nam dane bezpośrednio, a ustalenie jednego właściwego typu „korespondencji” pomiędzy faktycznymi stanami rzeczy a twierdzeniami na ich temat przekracza nasze możliwości. Wskazanie jednej z potencjalnie nieskończenie wielu relacji tego rodzaju jako zasady prawdziwości nie jest możliwe; prawda „korespondencyjna”, stanowiąc relację odniesienia do obiektów i zdarzeń poza umysłem, sama należy do elementów zewnętrznych wobec myśli i języka, a zatem do tego, co bezpośrednio niedostępne i zrelatywizowane do teoriii ${ }^{19}$. Odnajdując się pomiędzy teoretycznymi wątpliwościami a wskazaniami praktyki życiowej i intelektualnej, Putnam uważa mimo wszystko, że

[...] jest jakaś idea prawdy, lub, skromniej: „trafności”, którą nieustannie się posługujemy, i która wcale nie jest tym samym, co właściwa realizmowi metafizycznemu idea opisu „korespondującego” z faktami noumenalnymi ${ }^{20}$.

Prawda określona przez Putnama jako „trafność” nie jest „[... ] niczym więcej niż wyidealizowaną, racjonalną akceptowalnością"21. Jako taka ma ona sens wewnętrzny, co oznacza jej ścisłe powiązanie z kontekstem teorii, której prawdziwość się stwierdza. Wewnętrzna prawdziwość orzekana może być o dwóch lub więcej różnych od siebie teoriach. Zdaniem Putnama, każda z nich może być równie „trafna”, dobra czy akceptowalna we właściwych sobie kontekstach ${ }^{22}$.

Kategorię wewnętrznej prawdziwości można próbować oddać na gruncie historii za pomocą pojęć takich jak „rzetelność”, „uczciwość” czy „wiarygodność”. Można przyjąć, że pojęcia te jako określniki poznania historycznego odpowiadają w zasadniczym stopniu temu, co Putnam rozumial przez „trafność” $i$ „akceptowalność”. Świadomość metodologiczna historyków obejmuje obecnie przeświadczenie, że „obiektywizm w naukach społecznych i humanistycznych oznacza raczej rzetelność i

18 Tamże, s. 66.

19 H. Putnam, Dlaczego świat nie jest wyrobem gotowym, [w:] Wiele twarzy realizmu i inne eseje, Warszawa 1998, s. 227-229, 232-233.

20 H. Putnam, Wobronie realizmu wewnętrznego, [w:] Wiele twarzy realizmu..., s. 447.

21 Tamże, s. 449.

22 Tamże, s. 447-449. 
uczciwość poznawczą niż traktowanie »obiektów badania«, czyli ludzi, »jak rzeczy«"33. $\mathrm{Z}$ perspektywy narratywistycznej teorii historii, to, co minione, stanowi przedmiot interpretacji, które z natury swej nie są nigdy prawdziwe absolutnie; w świetle źródeł historycznych mogą być one co najwyżej wiarygodne lub uczciwe ${ }^{24}$. Jak można by sądzić, owa tendencja do charakteryzowania poznania historycznego jako zorientowanego na rzetelność i wiarygodność w przedstawianiu przeszłości wskazuje na pewną kompatybilność pragmatycznej (wewnętrznej) koncepcji prawdy z faktycznymi uwarunkowaniami badań historycznych. Nie-obiektywny, wewnętrzny status prawdy ustalanej przez historyków znajduje swój wyraz przede wszystkim w fakcie powiązania prawdy historycznej z tym, co przy użyciu terminologii Putnama nazwać by można „kontekstem praktyki intelektualnej”. W wypadku nauk historycznych, kontekst ów wyznaczany jest przez konkretną bazę źródłową, a także zastaną wiedzę na temat badanego zagadnienia. Potwierdza to praktyka badawcza historii, zgodnie z którą twierdzenia dotyczące zjawisk z przeszłości odnosi się nie tyle do przeszłości samej, co jej śladów i świadectw oraz korpusu uznawanych narracji historycznych ${ }^{25}$. Zgodnie z ową praktyką - co podkreśla Krzysztof Zamorski - historyczna zasada referencyjności poznania ustawia refleksję nad przeszłością w relacji odniesienia do treści zawartych w przekazie źródłowym i funkcjonujących już interpretacjach historycznych ${ }^{26}$. Jak się wydaje, elementy te, stanowiąc specyficzną podstawę pracy historyka, „kontekstualizują” wartość poznawczą jej rezultatów: relatywizują ich prawdziwość do udostępnianych przez nie danych i informacji. Ustalenie prawdy historycznej jako wiarygodnej interpretacji tego, co minione, jest każdorazowo czynnością realizowaną w ściśle ograniczonym i swoistym dla nauk historycznych polu informacyjnym. To właśnie nadaje jej, by tak rzec, „walor wewnętrzności”. Tytułem uzupełnienia warto zauważyć, że prawda historyczna w tej postaci jest, co zgadzałoby się z poglądem Putnama, „nie-korespondencyjna”; jako taka nie pretenduje ona do bycia jedną jedyną prawdą obiektywną i z zasady dopuszcza pluralizm prawd. Wskutek aktywności historyka, gdy idzie o wybór i krytykę źródeł ${ }^{27}$, kontekst badania historycznego nie jest wciąż tym samym polem informacji, a ulegając zmianom, warunkuje współistnienie odmiennych ujęć danego wycinka przeszłości jako ujęć równie „trafnych”

23 W. Werner, Wprowadzenie do historii, Warszawa 2012, s. 72.

24 E. Domańska, Filozoficzne rozdroża..., [w:] red. E. Domańska, J. Topolski, W. Wrzosek, Między modernizmem a postmodernizmem..., s. 23.

25 J. Topolski, Problemy prawdy..., [w:] red. E. Domańska, J. Topolski, W. Wrzosek, Między modernizmem a postmodernizmem..., s. 35 .

26 W ujęciu Krzysztofa Zamorskiego, referencyjność poznania historycznego, to stała możliwość jego weryfikowania na podstawie materiałów źródłowych oraz literatury przedmiotu, w czym pomocny jest między innymi towarzyszący narracji historycznej system przypisów. K. Zamorski, Dziwna rzeczywistość..., s. 139.

27 W. Werner, Wprowadzenie do..., s. 89. 
i „akceptowalnych”, to znaczy równie rzetelnych i wiarygodnych we właściwych sobie kontekstach. Jerzy Topolski, dostrzegając analogię pomiędzy uwewnętrznioną prawdą Quine’a i Putnama a prawdą historyczną, postuluje, by historycy porzucili myślenie z perspektywy jednej tylko prawdy i przyjęli bliższą ludzkiej praxis koncepcję wielu prawd wewnętrznych ${ }^{28}$.

Z uwagi na wskazane wcześniej związki idei racjonalności z kategorią prawdy, rozumienie prawdy historycznej z pozycji „realizmu wewnętrznego” skłania do zastanowienia, w jaki sposób zjawisko to określa status racjonalności nauk historycznych: czy i jak wewnętrzny charakter prawdy historycznej wpływa na pojęcie tego, co racjonalne, w naukowej historiografii. Jeżeli przyjąć pogląd pragmatyzmu, że uwewnętrznienie kategorii prawdy historycznej nie oznacza jej zanegowania, a jedynie pewne osłabienie na mocy krytycznej refleksji epistemologicznej, można przypuszczać, iż pytanie o racjonalność nauk historycznych ma swą przedmiotową ważność, aczkolwiek kierunek poszukiwania odpowiedzi na nie jest inny niż ten wyznaczany dotychczas z perspektywy klasycznej koncepcji prawdziwości. Osłabienie znaczenia prawdy w badaniu historycznym - rozumiane tu jako jej „odobiektywizowanie” - przekłada się, co wolno założyć, na potrzebę poszukiwania w obszarze historii adekwatnie osłabionej wersji racjonalności. Można by zaryzykować tezę, że prawdzie historycznej w rozumieniu kontekstowym (wewnętrznym) odpowiadać powinna per analogiam kontekstowa (wewnętrzna) racjonalność nauk historycznych.

Odgadując założenia możliwej teorii wewnętrznej racjonalności nauk historycznych, należy przypuścić, że racjonalność byłaby w jej ramach nie tyle zdolnością adekwatnego odzwierciedlania minionej rzeczywistości w poznaniu czy języku, ile dyspozycją do jej „trafnego” interpretowania w świetle przyjętych źródeł. Można by określić ją jako dyspozycję historyków do ustalania „trafności” sądów historycznych w różnych kontekstach badawczych: jako kompetencję do uzyskiwania „akceptowalności” narracji historycznych między innymi w odniesieniu do odmiennych zakresowo informacji źródłowych. Jak się wydaje, wewnętrzną racjonalność nauk historycznych utożsamiać można z realizowaną kontekstowo krytyczną formą refleksji nad dziejami, zdolnej weryfikować wiedzę o przeszłości w granicach odmiennych pól odniesień natury źródłowej i inter-tekstualnej. Hipotetycznie, racjonalność ta - profilowana pod kątem implementowania do historii idei prawdy wewnętrznej - wyraża się adekwatnie poprzez „rzetelność” i „uczciwość” poznawczą historyków - zgodnie z wcześniej przyjętą wykładnią obu terminów.

28 J. Topolski, Problemy prawdy..., [w: ] red. E. omańska, J. Topolski, W. Wrzosek, Między modernizmem a postmodernizmem..., s. 38 . 
Generalizując, krytyka klasycznej koncepcji prawdy oraz postulat, by w historii posługiwać się pojęciem prawdy wewnętrznej, otwiera przed historykami możliwość poszukiwania specyficznej (wewnętrznej) racjonalności ich dziedziny wiedzy: racjonalności wpisanej w szczególnego rodzaju uwarunkowania badań historycznych i „niezapożyczanej” do historii „z zewnątrz”, z innych dyscyplin.

Niewykorzystanie możliwości, jaką otwiera koncepcja realizmu wewnętrznego, powoduje, że namysł nad racjonalnością historii jako odrębną dyscypliną wiedzy odbywa się po większej części w przestrzeni badawczej filozofii, tradycyjnie uważanej za właściwy obszar do analiz tego, co racjonalne, we wszystkich jego aspektach. Dla teorii historii może to mieć ten skutek, iż jej próby odpowiedzi na pytanie, czym jest racjonalność nauk historycznych, oscylować będą wokół tradycyjnych filozoficznych tez na temat rozumności historii i implikowanych przez nie schematów interpretacyjnych. Ich zastosowanie - zwłaszcza, gdy chodzi o tezy maksymalistycznie zorientowanej filozofii - generuje tendencję do postrzegania racjonalności nauk historycznych przede wszystkim przez pryzmat zewnętrznego wobec historii (transcendentnego lub transcendentalnego) wzorca rozumności. Nieraz, jak można wykazać, prowadziło to bądź do neutralizowania przez rozum autonomii historii, bądź do negowania prawomocności związków historii z rozumem.

Pierwsze ze zjawisk odnosi się między innymi do dziewiętnastowiecznych filozofii dziejów. Wypracowując pojęcie racjonalności tego, co historyczne, filozofie te wskazywały zwykle na określoną logikę rozwoju dziejów, w świetle której historia przestawała być niezrozumiałym chaosem pojedynczych zdarzeń i stawała się pojmowalnym dla rozumu procesem rozwijającym się planowo od swego początku po cel ostateczny. Historiozofie XIX wieku uzyskiwały owo pojęcie, zakładając możliwość wynajdywania pod zmiennością historyczną pewnego stałego elementu (zasady, prawa ... ), który urzeczywistniając się dzięki tej zmienności, dowodzi, że bieg dziejów jest rozumny i rozumne jest również poznanie dziejów, gdy potrafi ono ów niezmienny (nie-historyczny) element ująć. Przy powyższym założeniu podstawę stwierdzenia racjonalności tego, co historyczne, stanowiła zatem relatywizacja historii jako dziedziny empirycznej do pierwiastka ratio lokalizowanego a priori poza czy też ponad empirią ${ }^{29}$. Omawiane koncepcje konstatowały rozumność historii, neutralizując jej cechy swoiste i uznając ich redukowalność do sfery zasadniczo odmiennej niż historia. Operacja ta - znana między innymi z filozofii Hegla - powoduje, że „[...] wszystko to, co istniejące, poszczególne i nietożsame, spada do poziomu przejściowych form

29 A. Sikora, Historia i prawdy wieczne, Warszawa 1977, s. 5-11. 
dookreślania się rozumowej całości [...] $]^{\text {30 }}$. Ustalona tą drogą rozumność historii wymaga, by tak rzec, uprzedniego przezwyciężenia historyczności samej historii. Jak można by sądzić, wątpliwe jest, by usiłujące podążać tym śladem poszukiwanie racjonalności nauk historycznych mogło spełnić swoje zadanie w sensie ścisłym, to znaczy dać pojęcie racjonalności przynależne owym naukom wyłącznie w ich granicach: dać pojęcie racjonalności historii uwzględniające jej odrębny profil epistemologiczny.

Wskutek uznania autonomii historii jako nauki empirycznej, myśl filozofii dziejów poddano krytyce. W świetle owej krytyki nie sposób redukować historii do ahistorycznej rozumności, ani też czynić niczego innego, co pozwoliłoby dowieść, że historia lub wiedza o niej są racjonalne. Leszek Kołakowski, rozumiejąc historię przez pryzmat założeń historyzmu, uważał, że przykładanie do historii ogólnych i niezmiennych wzorców rozumności wykracza poza zasięg naukowego uzasadnienia. Traktując historię jako empiryczną dziedzinę tego, co indywidualne i zmienne, twierdził, że teza o racjonalności historii stanowić może jedynie swoisty akt wiary, którego nie potrafimy „[...] wintegrować $[\ldots]$ w żadną metodę prawomocną na gruncie historiografii” ${ }^{3}$. Idea racjonalności historii, to w ujęciu Kołakowskiego konstrukcja zakładająca

[...] nieempiryczną potencję, która realizuje się dzięki historii, ale sama nie jest jej częścią ani wytworem, nie może być tedy ze znajomości dziejów wydobyta, lecz tylko wiedzy historycznej narzucona jako sposób interpretacji ${ }^{32}$.

Wydaje się, że na płaszczyźnie filozofii - tak tradycyjnej filozofii dziejów, jak i jej krytyki - główną trudność w dotarciu do racjonalności nauk historycznych stanowi założenie metafizyczne, zgodnie z którym rozumność odnajdywana w rzeczywistości (na przykład $\mathrm{w}$ historii) sytuowana jest $\mathrm{w}$ zasadniczo odmiennym porządku aniżeli sama rzeczywistość, w tym rzeczywistość historyczna ${ }^{33}$. Wskutek krytyki teorii historiozoficznych oraz upowszechnienia się zasad historyzmu założenie to implikuje nierozwiązywalny na drodze neutralizacji historyczności problem polaryzacji sfer tego, co historyczne, i tego, co racjonalne. Stan napięcia pomiędzy owymi sferami obrazuje funkcjonujące w filozofii rozróżnienie terminologiczne, sytuujące pojęcia historii i racjonalności na semantycznie przeciwstawnych sobie pozycjach. Zgodnie z tym rozróżnieniem, uważa się, że racjonalność, to domena ogólności, konieczności i niezmienności, a historia, to dziedzina tego, co jednostkowe, kontyngentne i prze-

30 A. Wawrzynowicz, Hegel i Adorno - opozycja dwóch koncepcji myślenia dialektycznego i dwóch wykładni racjonalności, Poznań 2001, s. 129.

31 L. Kołakowski, Rozumienie historii i zrozumiatość zdarzenia historycznego, [w: ] Kultura i fetysze, Warszawa 2009, s. 212.

32 L. Kołakowski, Rozumienie historii i zrozumiałość..., [w: ] Kultura i..., s. 214.

33 M. Poręba, Możliwość rozumu: ćwiczenia z metafizyki, Warszawa 2008, s. 526. 
mijające ${ }^{34}$. Wiąże się z tym uzasadniona obawa, iż koncentracja uwagi na pierwiastku ratio usuwa z pola widzenia wszystko, co ma wymiar historyczny ${ }^{35}$, uniemożliwiając pomyślenie poznania historycznego jako racjonalnego w swoistym dla niego znaczeniu. Teoria historii, o ile podziela intuicję nieprzystawalności dziedzin historii i rozumu, może znajdować kwestię racjonalności nauk historycznych jako problematyczną w powyższym sensie.

Z perspektywy filozofii, potrzebę przełamania problematycznego charakteru racjonalności tego, co historyczne, dostrzega obecnie Herbert Schnädelbach. Twierdzi on, że „racjonalizacja historii jest konieczna, abyśmy mogli zaczerpnąć z niej elementy racjonalności, które można by przypisać naszej tożsamości $[\ldots]^{\text {”36 }}$ - tożsamości istot uważających się zarazem za historyczne i rozumne. Fenomen ludzkiej tożsamości, łączącej w sobie elementy rozdzielane przez filozofię i naukę, zwraca uwagę Schnädelbacha na fakt, że historia człowieka jako istoty zorientowanej na racjonalność nie może być historią pozbawioną zupełnie wymiaru rozumności - bez jakiegokolwiek związku $\mathrm{z}$ ratio jej idea byłaby dla człowieka niepojmowalna mimo, że historiozoficzna teza o obiektywnie rozumnym biegu dziejów definitywnie utraciła aktualność.

Projekt Schnädelbacha zakłada wzajemne zbliżenie historii i racjonalności: próbę łącznego pomyślenia ogólności i indywidualności, konieczności i kontyngencji, niezmienności i przemijalności. Zadanie to, realizowane w warunkach po krytyce spekulatywnych teorii dziejów, wymaga przyjęcia do wiadomości, że racjonalność tego, co historyczne, może być tylko racjonalnością nie-obiektywną, ludzką, a zatem nieodzownie uhistorycznioną. Dochodzi tu do głosu pogląd, zgodnie z którym to, co w rzeczywistości historycznej rozpoznane zostaje jako racjonalne, samo nie może istnieć poza historią i w tym rozumieniu jest historyczne.

W świetle ustaleń Schnädelbacha, jedną z konsekwencji tej sytuacji stała się dostępność racjonalności dla instrumentarium badań historycznych: konsekwencją tą jest przesunięcie racjonalności w zakres przedmiotowy empirycznej nauki o historii, gdzie stanowi ona przede wszystkim przedmiot analiz metodologicznych, realizowanych środkami owej nauki ${ }^{37}$. Fakt ten włącza nauki historyczne w opisywaną przez Marcina Porębę reorientację poznawczą współczesnego myślenia naukowego. W jej wyniku współczesne nauki zaczynają (przy użyciu własnych metod) podejmować kwestie bardziej zasadnicze i istotowe, a niegdyś zarezerwowane nieomal wyłącznie dla filozofii. Wśród nich jedną z centralnych jest kwestia racjonalności. Jak zauważa

34 H. Schn囚delbach, Wprowadzenie. O rozumności historii i historyczności rozumu, [w:] Rozum i historia. Odczyty i rozprawy, Warszawa 2001, s. 8.

35 Tamże, s. 15.

36 Tamże, s. 16.

37 Tamże, s. 8-14. 
Poręba, zarówno logika matematyczna, jak i teoria względności czy mechanika kwantowa, zawierają w sobie odniesienie do podstaw własnego poznania, to jest, do racjonalności, której one same są wyrazem ${ }^{38}$. Odniesienie to ma swe źródło w odkryciu immanentnych ograniczeń, jakie cechują racjonalność każdej dyscypliny naukowej i sprawiają, że racjonalność tę rozpoznajemy jako element dziedziny, której podstawę poznania ona stanowi ${ }^{39}$.

Przez owe immanentne ograniczenia rozumieć należy czynniki skłaniające do przyjmowania matematycznej, fizykalnej bądź uhistorycznionej interpretacji ratio danej nauki. Czynniki, sugerujące uznanie historycznego wymiaru racjonalności, są obecnie, co podkreśla Schnädelbach, silne i liczne ${ }^{40}$. Przy wnioskach Poręby, okoliczność ta daje naukom historycznym podstawę do zajmowania się racjonalnością jako ich własnym przedmiotem. Na tym gruncie otrzyma ona, jak można by sądzić, status racjonalności wewnętrznej, w dużym stopniu kompatybilnej z prawdą historyczną pojętą jako prawda wewnętrzna w rozumieniu Putnama czy Quine’a. Wydaje się, że wybór tak ujętej prawdy historycznej jako kategorii otwierającej perspektywę do badań nad racjonalnością nauk o historii pozwala uzyskać wyniki zbieżne z innymi ustaleniami, wprost lub pośrednio rozstrzygającymi o współczesnym usytuowaniu problematyki racjonalności na płaszczyźnie teorio-historycznej (Schnädelbach, Poręba): przynosi rezultaty potwierdzające zjawisko przejmowania przez współczesną naukę (w tym historię) niektórych ważnych problemów filozoficznych i nadawanie im wewnętrznego sensu w ramach poszczególnych dyscyplin wiedzy. Mając na uwadze podkreślaną od początku zależność pojęcia racjonalności w danym obszarze od uznawanej w nim koncepcji prawdy, przyjąć można, że szeroko kwestionowane w teorii historii klasyczne („korespondencyjne”) rozumienie prawdy, a także postulat imple-

38 W wypadku teorii względności i mechaniki kwantowej wspomniane odniesienie polega na zaproponowaniu fizykalnej interpretacji działań poznawczych (czynności obserwacyjnych, pomiarowych, eksperymentalnych) oraz podstawowych dla tych teorii pojęć teoretycznych: czasu, przestrzeni, relacji przyczynowo-skutkowej. Logika matematyczna dokonała czegoś analogicznego, ujmując w ścisły i matematyczny sposób zagadnienie granic poznania matematycznego, w tym między innymi kwestię podstaw dowodów twierdzeń matematycznych.

39 M. Poręba, Możliwość rozumu ... , s. 524-526. Na poparcie uwag Marcina Poręby wskazać można definicję racjonalności podaną przez Wolfganga Welscha. Racjonalność w jego ujęciu, to zdolność stosowania pojęć w obrębie jednej dziedziny. Naturalną konsekwencją przyjęcia tej definicji jest uznanie - jako punktu wyjścia współczesnej myśli - pluralizmu form racjonalności: form odpowiadających poszczególnym obszarom ludzkiego doświadczenia czy wiedzy. W. Welsch, Nasza postmodernistyczna moderna, Warszawa 1998, s. 406-407. Efekt multiplikacji typów racjonalności, to zjawisko rozpoznawane także z pozycji współczesnej filozofii nauki, dla której założenie o istnieniu jednego, uniwersalnego rozumu całej nauki przestało być założeniem obowiązującym bezwzględnie i powszechnie. Pod wpływem autorów takich, jak Paul Feyerabend, mówi się obecnie nie tyle o jednym wzorcu racjonalności naukowej, co o wielu wzorcach ściśle zależnych od czynników lokalnych i wewnątrz-systemowych. D. Mendrala, Anarchistyczna negacja metody naukowej u Paula K. Feyerabenda, [w:] red. A. Kiepas, Człowiek wobec wyzwań racjonalności, Katowice 2002, s. 57-59.

40 H. Schnädelbach, O dialektyce rozumu historycznego, [w:] Rozum i..., s. 51. 
mentowania do historii idei prawdziwości kontekstualnej, wewnętrznej (Topolski), stawia nauki historyczne przed względnie nowym dla nich zadaniem: samodzielnym zbadaniem własnej uhistorycznionej racjonalności. Przywołane w niniejszym tekście poglądy filozoficzne i teorio-historyczne wydają się od pewnego czasu kreować potrzebę podjęcia takiej próby. Co więcej, stwarzają dla jej realizacji warunki, których wcześniej nie generowała ani tradycyjna filozofia dziejów, ani klasyczny historyzm.

Konkluzja powyższa z pewnością nie zamyka dyskusji w kwestii efektywności badań nauk historycznych nad ich własną racjonalnością. Kwestia ta wydaje się być wciąż otwarta i budzić może określone wątpliwości. Posiłkując się wnioskami Herberta Schnädelbacha, przyjęto tu, że uznanie racjonalności empirycznego poznania historycznego zakłada zbliżenie tego, co racjonalne, i tego, co historyczne, skutkując nieodzownie uhistorycznieniem racjonalności. Wątpliwość, jaką nasuwa ten fakt, polega na obawie, czy owo uhistorycznienie nie grozi całkowitą redukcją tego, co racjonalne, do historyczności. Mogłoby się tak zdarzyć, gdyby nauki historyczne miały okazać się niezdolne do utrzymania pewnej pojęciowej odrębności uhistorycznionej racjonalności i potraktowały ją wyłącznie jako fenomen historyczny. W takim wypadku racjonalność nauk o historii byłaby nieodróżnialna od pozostałych zjawisk w rzeczywistości historycznej i nie pozwalała ująć się jako podstawa wyjaśniająca poznawanie owej rzeczywistości przez naukową historiografię. Patrząc z perspektywy Schnädelbacha, byłby to niewątpliwie fakt osłabiający postulat badania racjonalności nauk historycznych przez nie same. Zgodnie ze stanowiskiem tego autora, nauki historyczne, by wyjaśnić wewnętrznie, na czym polega ich racjonalność, powinny zachować równy dystans zarówno wobec racjonalistycznego absolutyzmu, jak relatywizmu historycznego. Oznacza to konieczność rozszerzenia przez te nauki perspektywy teoretycznej tak, aby to, co racjonalne, rozumiane było w nich zarazem historycznie i teoretycznie. To, czy refleksja naukowo-historyczna zdolna jest zrealizować powyższe wymagania, nie wydaje się jeszcze kwestią przesądzoną i może być przedmiotem sporu. Fakt, że ostatecznie Schnädelbach przyznaje tę zdolność nie naukom historycznym, ale odpowiednio zaprojektowanej filozoficznej teorii racjonalności, wskazuje na to wyraźnie ${ }^{41}$.

41 H. Schnädelbach: Wprowadzenie... [W:] Rozum i..., s. 9, 15 - 17. 